\title{
Antitumor activity of nimotuzumab in combination with cisplatin in lung cancer cell line A549 in vitro
}

\author{
YANHONG YANG $^{1}$, WENWEN ZHOU $^{1}$, JIANDONG WU $^{1}$, LIXIN YAO $^{1}$, \\ LEI XUE ${ }^{1}$, QIANYI ZHANG ${ }^{2}$, ZHENZHEN WANG ${ }^{1,3}$, XIAOYU WANG $^{3}$, \\ SHU DONG ${ }^{4,5}$, JIANGMAN ZHAO ${ }^{4,5}$ and DUANDUAN YIN ${ }^{1}$ \\ ${ }^{1}$ Department of Oncology, Qinhuangdao No. 1 People's Hospital, Qinhuangdao, Hebei 066000, P.R. China; \\ ${ }^{2}$ College of Pharmacy, University of Tasmania, Hobart, TAS 7001, Australia; ${ }^{3}$ Postgraduate College of \\ Chengde Medical University, Chengde, Hebei 067000; ${ }^{4}$ Biotecan Medical Diagnostics Co., Ltd.; \\ ${ }^{5}$ Department of Medicine, Zhangjiang Center for Translational Medicine, Shanghai 201203, P.R. China
}

Received June 17, 2016; Accepted January 3, 2018

DOI: $10.3892 / \mathrm{ol} .2018 .7923$

\begin{abstract}
Nimotuzumab, a humanized IgG1 monoclonal antibody against epidermal growth factor receptor (EGFR), increases radiosensitivity in lung cancer. Cisplatin is an effective antitumor agent in lung cancer. In the present study, the antitumor activity of nimotuzumab combined with cisplatin was investigated in A549 lung cancer cells. Viability, cell cycle distribution and cyclin D1 expression were assessed following treatment with nimotuzumab alone, cisplatin alone, nimotuzumab in combination with cisplatin, and nimotuzumab followed sequentially by cisplatin. The inhibitory effect on cell viability of nimotuzumab sequentially followed by cisplatin was higher compared with cisplatin alone $(82.17 \pm 1.62$ vs. $56.97 \pm 1.42 \%)$. Compared with treatment by cisplatin alone, cell cycle analysis by flow cytometry demonstrated that the percentage of cells in the $\mathrm{G}_{0} / \mathrm{G}_{1}$ phase was increased when A549 cells were treated with nimotuzumab followed sequentially by cisplatin $(P<0.01)$. However, the proportion of cells in $G_{0} / G_{1}$ phase was decreased when A549 cells were treated with nimotuzumab and cisplatin simultaneously compared with cisplatin alone $(\mathrm{P}<0.05)$. Cyclin D1 expression was decreased in all chemotherapy treatment groups; the most significant decrease was in A549 cells treated with nimotuzumab followed sequentially by cisplatin. Nimotuzumab may enhance the
\end{abstract}

Correspondence to: Dr Duanduan Yin, Department of Oncology, Qinhuangdao No. 1 People's Hospital, 258 Wenhua Road, Qinhuangdao, Hebei 066000, P.R. China

E-mail: 502549237@qq.com

Ms. Jiangman Zhao, Department of Medicine, Zhangjiang Center for Translational Medicine, 180 Zhangheng Road, Shanghai 201203, P.R. China

E-mail: jiangzhao@biotecan.com

Key words: nimotuzumab, cisplatin, A549 cells, cyclin D1, antitumor activity antitumor activity of cisplatin on A549 cells. The cell cycle arrest at $G_{0} / G_{1}$ observed may have been due to decreased cyclin D1 levels. Potential antagonism was identified when A549 cells were treated with nimotuzumab and cisplatin simultaneously, indicating that targeted therapy may be more effective when administered prior to conventional chemotherapy.

\section{Introduction}

Lung cancer has been the most common cancer worldwide, and the leading cause of cancer-associated mortality, since 1985 (1). The 5-year survival rate for lung carcinoma overall is poor, at $16-17 \%$ (2). Surgery is not suitable for the majority of patients with lung cancer, as diagnoses are often obtained at advanced disease stages. The standard of care for advanced non-small cell lung cancer (NSCLC) is cisplatin in combination with 1 to 3 of the following drugs: Paclitaxel, gemcitabine and docetaxel (3). The efficacy of chemotherapy is limited due to its side effects and the lack of response in certain sub-populations of patients. Research efforts have focused on identifying molecular targets and developing molecular-targeted therapies based on the understanding of the molecular abnormalities associated with lung cancer (4-6).

Insight into the pathobiology of NSCLC has facilitated the development of targeted molecular therapies that target specific mutations that serve critical roles in the progression to aggressive disease. Mutations in the epidermal growth factor receptor $(E G F R), K R A S$ and anaplastic lymphoma kinase $(A L K)$ genes are mutually exclusive in patients with NSCLC, and targeted therapy may be affected due to the existence of one mutation in lieu of another. Therefore, the detection of these mutations and the subsequent tailoring of therapy accordingly are widely accepted as standard practice $(7,8)$. EGFR is expressed on the cell surface of a substantial proportion of NSCLC tumors. EGFR overexpression is observed in $50-80 \%$ of patients with NSCLC, and $65 \%$ of these individuals also exhibit an EGFR gene copy number amplification $(9,10)$. 
EGFR is a member of the tyrosine kinase growth factor receptor family. Its ligands, EGF and transforming growth factor- $\alpha$, bind to the ectodomain of EGFR to elicit biological effects through the RAS/RAF/mitogen-activated protein kinase kinase 1/extracellular signal-related kinase pathway, the phosphoinositide 3-kinase/AKT pathway, the phospholipase-C $\gamma /$ protein kinase $\mathrm{C}$ pathway, the SRC/signal transducer and activator of transcription pathway and the corresponding crosstalk, leading to the regulation of cellular proliferation, survival, apoptosis, invasion and metastasis $(11,12)$. The overexpression of EGFR usually indicates rapid progress, resistance to chemoradiotherapy and a poor prognosis for patients with lung cancer $(13,14)$. Various small-molecule tyrosine kinase inhibitors (TKIs) and anti-EGFR antibodies targeting EGFR have been developed over the previous 30 years. EGFR TKIs directly bind to the kinase domain and block its kinase activity, including the first-generation EGFR TKIs Erlotinib and Gefitinib, second-generation Aftinib and third-generation AZD9191. Conversely, EGFR-targeting antibodies such as Cetuximab, Panitumumab and nimotuzumab bind extracellularly, blocking ligand binding and preventing receptor dimerization (15).

Nimotuzumab, also known as h-R3, is a humanized IgG1 isotype monoclonal antibody against EGFR $(16,17)$, which is different from Cetuximab and Panituzumab as it demonstrates different pharmacokinetic traits, including a prolonged half-life, and elevated area under the curve compared with Cetuximab at the equivalent dose level (6). Safety data has demonstrated that nimotuzumab rarely causes severe dermatological toxicity, which is the most common adverse event resulting from Cetuximab and Panitumumab treatment; therefore, nimotuzumab is expected to improve the quality of life for patients receiving EGFR inhibition therapy (18). Randomized studies have demonstrated that nimotuzumab, combined with irradiation or chemoradiotherapy, may provide an improvement in prognosis to patients with head and neck cancer (18), gliomas (19) and esophagus squamous cell carcinoma (20).

Considering that patients with NSCLC diagnosed in the advanced stage usually exhibit a poor survival rate, EGFR inhibition alone, or combined with other options, in the treatment of NSCLC has become an attractive strategy validated in numerous pre-clinical and preliminary clinical trials (21-23). This has led to a further phase III randomized study to evaluate the efficacy of the combination of nimotuzumab with other chemotherapy drugs as a first line treatment for stage IIIB-IV NSCLC (24). A431 cells, a vulvar epidermoid carcinoma cell line with high EGFR expression demonstrated less receptor activation upon ligand binding when treated with nimotuzumab (25). Nimotuzumab is equally successful as an EGFR inhibitor in normal and mutant backgrounds (26). Xenograft models have confirmed this antitumor effect in A431 cells in mice in vivo. In addition, in vivo data indicated significant antitumor effects of nimotuzumab in xenografts utilizing the NSCLC H460, Ma-1 and H292 cell lines (26).

In the present study, the inhibitory effect of nimotuzumab combined with cisplatin against lung cancer cell growth was investigated.

\section{Materials and methods}

Cell culture. The A549 human lung adenocarcinoma epithelial cell line (supplied by the Central Laboratory of Qinhuangdao No. 1 People's Hospital) was cultured in Dulbecco's modified Eagle's medium (Gibco; Thermo Fisher Scientific, Inc., Waltham, MA, USA) containing $10 \%$ fetal bovine serum (FBS; Zhejiang Tianhang Biotechnology Co., Ltd., Huzhou, China), $1 \mathrm{U} / \mathrm{ml}$ penicillin and $1 \mathrm{mg} / \mathrm{ml}$ streptomycin at $37^{\circ} \mathrm{C}$, with $5 \% \mathrm{CO}_{2}$ and $95 \%$ humidity.

Reagents. Cisplatin was purchased from Qilu Pharmaceutical, Co., Ltd. (Shandong, China). Nimotuzumab was purchased from Biotech Pharmaceutical Co., Ltd. (Beijing, China).

Cell proliferation assays. Cell viability was measured using the MTT colorimetric assay, as described previously (27). Briefly, $100 \mu \mathrm{l}$ cell suspension was inoculated in each well of 96-well plates at the density of $3 \times 10^{4}$ cells/well. At $12 \mathrm{~h}$, the medium was removed by aspiration and replaced with $100 \mu \mathrm{l}$ culture medium without serum, as serum may alter the effects of the drugs, and cultured for a further $12 \mathrm{~h}$. The medium was then removed and replaced by the experimental medium containing $1 \%$ FBS.

A series of MTT assays were then performed to evaluate the effects of nimotuzumab combined with cisplatin on A549 cells at different time-points for 5 treatment groups: Group A, $200 \mu \mathrm{g} / \mathrm{ml}$ nimotuzumab; group B, $2 \mu \mathrm{g} / \mathrm{ml}$ cisplatin; group C, $200 \mu \mathrm{g} / \mathrm{ml}$ nimotuzumab for $24 \mathrm{~h}$, then the supernatant was removed and replaced with $2 \mu \mathrm{g} / \mathrm{ml}$ cisplatin; group D, treatment with cisplatin and nimotuzumab simultaneously; group E, treatment with fresh culture medium containing $1 \%$ FBS only. The treatments were performed for 24, 48 and $72 \mathrm{~h}$. Following incubation, MTT solution $(20 \mu 1,5 \mathrm{mg} / \mathrm{ml})$ was added to each well, and the plates were incubated in the dark for $4 \mathrm{~h}$ at $37^{\circ} \mathrm{C}$, followed by the removal of the culture medium and addition of $100 \mu \mathrm{l}$ dimethyl sulfoxide. The absorbance was measured at 492 with $655 \mathrm{~nm}$ as the reference wavelength. A total of 6 parallel wells were used for each group, and all experiments were performed in triplicate. The inhibitory rate was calculated as follows: Cell growth inhibitory rate $(\%)=(\mathrm{OD}$ value in blank group - OD value in experiment group)/OD value in blank group x $100 \%$.

Cell cycle analysis. The cell cycle distribution was evaluated by flow cytometry using Vindelov's method (28). Briefly, A549 cells were harvested following treatment with either nimotuzumab or nimotuzumab combined with cisplatin, as aforementioned. Then, cells were treated with $0.25 \%$ trypsin to prepare single cell suspensions. The cells were transferred into $10 \mathrm{ml}$ centrifuge tubes and centrifuged at $4^{\circ} \mathrm{C}$ at $580 \mathrm{x} \mathrm{g}$ for $5 \mathrm{~min}$. The precipitate was collected, washed once with 1X PBS and processed for cell cycle analysis by flow cytometry. The cells were fixed in $75 \%$ ethanol and incubated at $4^{\circ} \mathrm{C}$ overnight. The fixed cells were centrifuged at $4^{\circ} \mathrm{C}$ at $145 \mathrm{x} \mathrm{g}$ for $5 \mathrm{~min}$ and washed twice with cold PBS. RNase A $(20 \mu \mathrm{g} / \mathrm{ml})$ and propidium iodide staining solution $(50 \mu \mathrm{g} / \mathrm{ml})$ were added to the cells and incubated for $30 \mathrm{~min}$ at $37^{\circ} \mathrm{C}$ in the dark. The 
Table I. Cell cycle distribution in each group following treatment for $48 \mathrm{~h}$.

Treatment group, $\%$

Cell cycle phase A, Nimotuzumab B, Cisplatin C, Sequential treatment D, Simultaneous treatment E, Untreated control

\begin{tabular}{lrrrrr}
\hline $\mathrm{G}_{0} / \mathrm{G}_{1}$ & $61.72 \pm 1.68$ & $66.40 \pm 2.31$ & $72.23 \pm 2.07$ & $62.28 \pm 1.68$ & $58.25 \pm 1.07$ \\
$\mathrm{~S}$ & $12.32 \pm 1.32$ & $8.78 \pm 0.91$ & $5.87 \pm 0.78$ & $11.01 \pm 1.37$ & $15.35 \pm 0.54$ \\
$\mathrm{G}_{2}-\mathrm{M}$ & $24.91 \pm 0.62$ & $24.48 \pm 2.80$ & $24.16 \pm 1.86$ & $26.71 \pm 1.31$ & $26.40 \pm 0.53$
\end{tabular}

Data are presented as the mean \pm standard deviation.

percentage of cells in each phase of the cell cycle was determined with ModFit LT 4.0 software (Verity Software House, Inc., Topsham, ME, USA). Experiments were performed at least twice.

Western blot analysis. The cell culture supernatant was removed, and the cells were washed in $4 \mathrm{ml}$ PBS, then centrifuged at $4^{\circ} \mathrm{C}$ at $900 \mathrm{xg}$ for $5 \mathrm{~min}$. The supernatant was discarded and the cells were washed repeatedly with PBS. A total of $200 \mu$ l RIPA lysis buffer (cat. no. P0013B; Beyotime Institute of Biotechnology, Shanghai, China) was added, the cells were lysed by shaking the flask for $40 \mathrm{~min}$ and cell lysate was transferred to $1.5 \mathrm{ml}$ centrifuge tube. The cell lysates were centrifuged at $4^{\circ} \mathrm{C}$ at $10,000 \mathrm{x}$ g for $15 \mathrm{~min}$ and the supernatant was transferred to a new centrifuge tube; tubes were stored at $-80^{\circ} \mathrm{C}$ until subsequent use.

Protein was quantified using the Enhanced BCA Protein Assay kit (cat. no. P0009; Beyotime Institute of Biotechnology). Whole cell extracts were subjected to SDS-PAGE (with a 5\% stacking gel and a $12 \%$ separating gel) and transferred to a nitrocellulose membrane for western blot analysis, with a loading quantity of $35 \mu \mathrm{g}$ protein/lane. Subsequently, 5\% skimmed milk powder was used for blocking at room temperature for $1 \mathrm{~h}$. Blots were incubated with monoclonal anti-cyclin D1 antibody produced in mice (1:200 dilution; cat. no. C7464; Sigma-Aldrich; Merck KGaA, Darmstadt, Germany), and anti- $\beta$-actin antibody (1:2,000 dilution; cat. no. A1978; Sigma-Aldrich; Merck $\mathrm{KGaA}$ ) overnight at $4^{\circ} \mathrm{C}$, washed with TBS-T, and incubated at room temperature for $1 \mathrm{~h}$ with horseradish peroxidase-labeled goat-anti-mouse $\operatorname{IgG}$ (1:200 dilution; cat. no. A0216; Beyotime Institute of Biotechnology). The protein bands were detected using 3,3'-diaminobenzidine tetrahydrochloride (DAB Horseradish Peroxidase Color Development kit; cat. no. P0202; Beyotime Institute of Biotechnology). $\beta$-actin served as a reference gene for the normalization of cyclin D1 expression. Densitometric analysis was performed using ImageJ 1.48 software (National Institutes of Health, Bethesda, MD, USA).

Statistical analysis. Statistical analyses of the experimental data were performed by two-way analysis of variance followed by Bonferroni's multiple comparison test with the SPSS, version 16.0 statistical software package (SPSS, Inc., Chicago, IL, USA). $\mathrm{P}<0.05$ was considered to indicate a statistically significant difference.

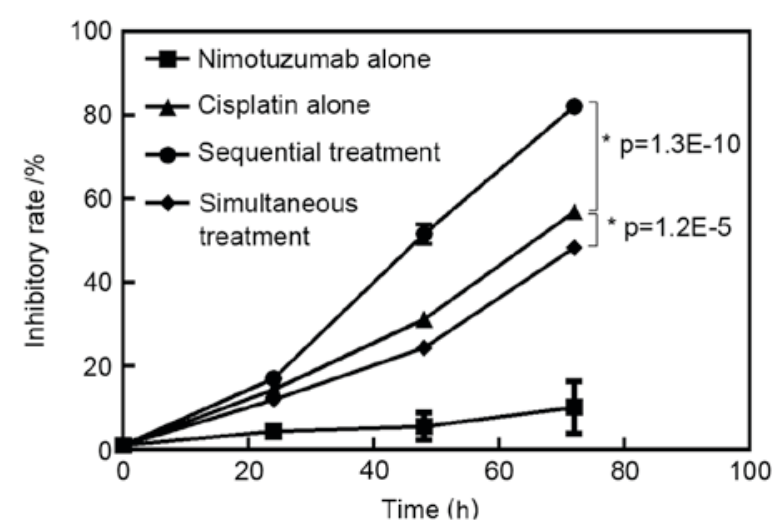

Figure 1. Inhibitory rate following treatment for treatment groups A-D at $72 \mathrm{~h}$, compared with an untreated control.

\section{Results}

Cell proliferation. The inhibitory rate for each group is presented in Fig. 1. Nimotuzumab alone and cisplatin alone inhibited A549 cell growth in a time-dependent manner $(\mathrm{P}<0.05)$. The inhibitory effect in the sequential treatment group was higher compared with the cisplatin treatment alone group $(\mathrm{P}<0.05)$. However, the inhibitory effect in the simultaneous treatment group was lower compared with that in cisplatin treatment alone group $(\mathrm{P}<0.05)$. The inhibitory rate in the sequential treatment group after $72 \mathrm{~h}$ treatment was $82.17 \pm 1.62 \%$ (Fig. 1).

Cell cycle analysis. To study the growth inhibitory effect of nimotuzumab in combination with cisplatin, the cell cycle distribution was analyzed with propidium iodide staining and flow cytometry. A typical $G_{0} / G_{1}$ arrest pattern in groups A-D was observed, particularly in the sequential treatment group (Fig. 2; Table I).

Cyclin D1 expression level. Cyclin D1 is a critical component of the cell cycle machinery. A number of types of human tumor have been identified to exhibit abnormally high levels of cyclin D1 (29). Compared with the control group, the expression of cyclin D1 was decreased in groups A-D following treatment, particularly in the sequential treatment group. However, cyclin D1 expression was higher in the simultaneous treatment group compared with that in the cisplatin alone group (Fig. 3). 

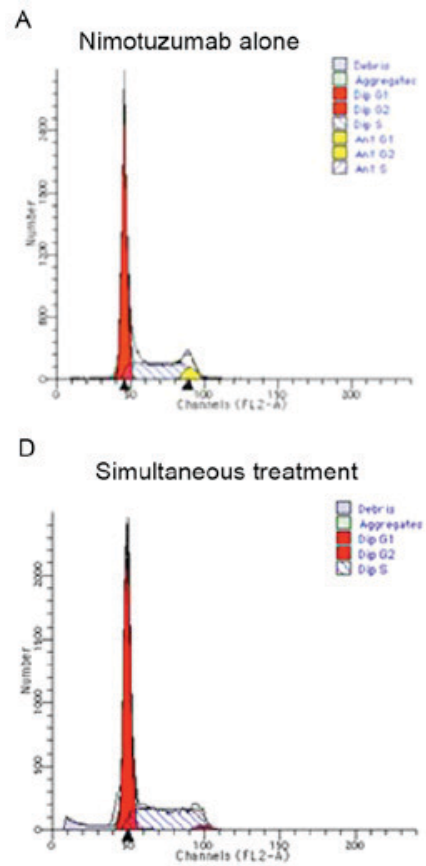

B

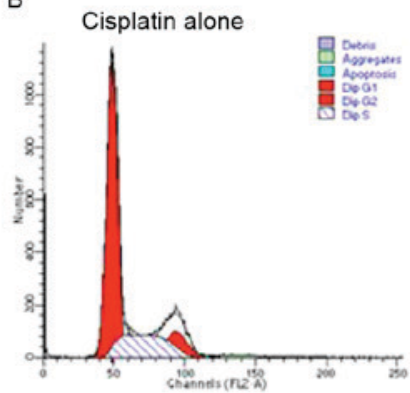

$E$

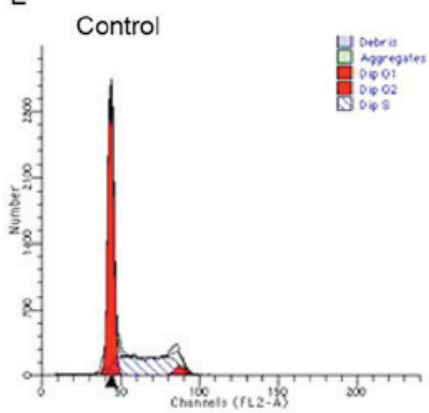

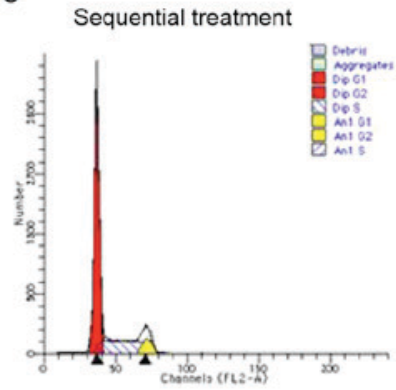

$\mathrm{F}$

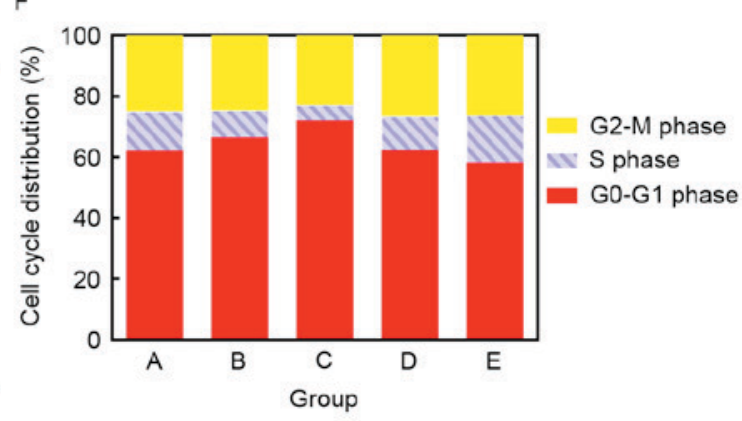

Figure 2. Effect of nimotuzumab or cisplatin on cell cycle distribution. Flow cytometry graph of treatment groups A-E, including: (A) nimotuzumab only, (B) cisplatin only, (C) nimotuzumab followed by cisplatin, (D) nimotuzumab and cisplatin simultaneously, and (E) untreated control, at $48 \mathrm{~h}$. (F) Quantified cell cycle distribution in each group at $48 \mathrm{~h}$.

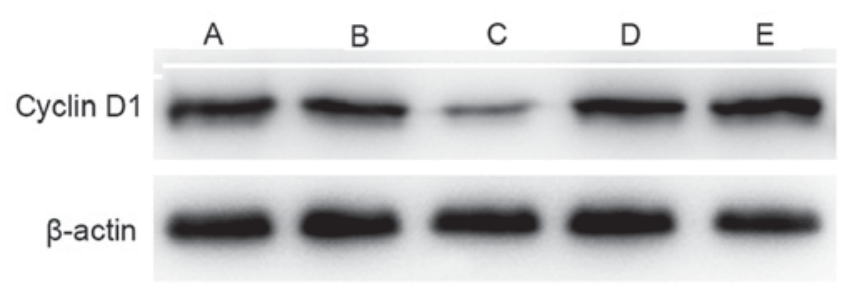

Figure 3. Cyclin D1 expression in A549 cells in groups A-E following treatment for 48 h. Lanes: A, nimotuzumab; B, cisplatin; C, nimotuzumab followed by cisplatin; D, nimotuzumab and cisplatin simultaneously; and E, untreated control.

\section{Discussion}

Nimotuzumab is well-tolerated, and efficacious against a number of tumor types (18,30-32). Numerous studies have demonstrated that for patients with advanced carcinoma, nimotuzumab combined with chemotherapy, radiotherapy or chemoradiotherapy was effective, and that it was well-tolerated and safe for conditions such as glioblastoma multiforme (GBM) and esophageal squamous cell cancer (ESCC); in combination with radiation therapy, nimotuzumab demonstrated few side effects (19) and improved the disease control rate in patients with GBM compared with radiation therapy alone (33). An open, uncontrolled phase II study indicated that the combination of nimotuzumab with concurrent chemoradiation was tolerated reasonably well in patients with advanced or metastatic ESCC, and increased the efficacy of treatment (34). Ramos-Suzarte et al (32) evaluated the adverse events of nimotuzumab combined with chemotherapy, radiotherapy or chemoradiotherapy in 835 patients pathologically diagnosed with malignant tumors in stage II-IV with metastasis or advanced carcinomas, and indicated that nimotuzumab with chemoradiotherapy was tolerated.

The present study demonstrated that A549 cell growth was inhibited somewhat by nimotuzumab alone, and was inhibited to a greater extent by cisplatin alone, consistent with one previous study (35). A549 cells pretreated with nimotuzumab for $24 \mathrm{~h}$ prior to cisplatin treatment exhibited a higher inhibitory rate compared with cells treated with cisplatin alone $(\mathrm{P}<0.05)$. A possible mechanism for the arrest at $\mathrm{G}_{0} / \mathrm{G}_{1}$ (Fig. 2; Table I) may have been the downregulation of cyclin D1 (Fig. 3). It is hypothesized that the antitumor effects of EGFR-specific monoclonal antibodies are produced by blocking the binding of ligands to EGFR. This may affect the activity of EGFR and its downstream signaling pathways, therefore inhibiting the proliferation of tumor cells, inducing cell cycle arrest and apoptosis.

However, a degree of antagonism was identified when A549 cells were treated with nimotuzumab and cisplatin simultaneously. Previous studies have reported similar conclusions; Ji et al (35) identified that nimotuzumab exhibited a weaker inhibition effect on human ESCC EC1 cells when administered in combination with other chemotherapeutic agents, although the extent was not significant, and Du et al (36) indicated that the combination of nimotuzumab with S-1-cisplatin provided no additional benefit compared with chemotherapy alone in the first-line treatment of unresectable or metastatic gastric cancer. Further studies investigating the molecular mechanisms of this potential antagonistic effect are required.

The present study provides evidence that the A549 human lung adenocarcinoma epithelial cell line was inhibited to a greater extent by treatment with cisplatin subsequent to pretreatment with molecularly targeted therapy. Further studies are required to assess the antitumor activity of nimotuzumab in combination with cisplatin in vivo, and its clinical significance. 


\section{References}

1. Provencio M, Isla D, Sánchez A and Cantos B: Inoperable stage III non-small cell lung cancer: Current treatment and role of vinorelbine. J Thorac Dis 3: 197-204, 2011.

2. Zeng H, Zheng R, Guo Y, Zhang S, Zou X, Wang N, Zhang L, Tang J, Chen J, Wei K, et al: Cancer survival in China, 2003-2005: A population-based study. Int J Cancer 136: 1921-1930, 2015.

3. Non-Small Cell Lung Cancer Treatment $\left(\mathrm{PDQ}^{\circledR}\right)$ : National Cancer Institute (US), 2013. https://www.cancer. gov/types/lung/patient/non-small-cell-lung-treatment-pdq.

4. Giaccone G, Herbst RS, Manegold C, Scagliotti G, Rosell R, Miller V, Natale RB, Schiller JH, Von Pawel J, Pluzanska A, et al: Gefitinib in combination with gemcitabine and cisplatin in advanced non-small-cell lung cancer: A phase III trial-INTACT 1. J Clin Oncol 22: 777-784, 2004.

5. Ciardiello F, Caputo R, Bianco R, Damiano V, Pomatico G, De Placido S, Bianco AR and Tortora G: Antitumor effect and potentiation of cytotoxic drugs activity in human cancer cells by ZD-1839 (Iressa), an epidermal growth factor receptor-selective tyrosine kinase inhibitor. Clin Cancer Res 6: 2053-2063, 2000.

6. Crombet T, Torres L, Neninger E, Catalá M, Solano ME, Perera A, Torres O, Iznaga N, Torres F, Pérez R and Lage A: Pharmacological evaluation of humanized anti-epidermal growth factor receptor, monoclonal antibody $\mathrm{h}-\mathrm{R} 3$, in patients with advanced epithelial-derived cancer. J Immunother 26: 139-148, 2003.

7. Keedy VL, Temin S, Somerfield MR, Beasley MB, Johnson DH, McShane LM, Milton DT, Strawn JR, Wakelee HA and Giaccone G: American Society of Clinical Oncology provisional clinical opinion: Epidermal growth factor receptor (EGFR) mutation testing for patients with advanced non-small-cell lung cancer considering first-line EGFR tyrosine kinase inhibitor therapy. J Clin Oncol 29: 2121-2127, 2011.

8. Stella GM, Scabini R, Inghilleri S, Cemmi F, Corso S, Pozzi E, Morbini P, Valentini A, Dore R, Ferrari S, et al: EGFR and KRAS mutational profiling in fresh non-small cell lung cancer (NSCLC) cells. J Cancer Res Clin Oncol 139: 1327-1335, 2013

9. Raben D, Helfrich B and Bunn PA Jr: Targeted therapies for non-small-cell lung cancer: Biology, rationale, and preclinical results from a radiation oncology perspective. Int J Radiat Oncol Biol Phys 59 (Suppl 2): S27-S38, 2004.

10. Cappuzzo F, Hirsch FR, Rossi E, Bartolini S, Ceresoli GL, Bemis L, Haney J, Witta S, Danenberg K, Domenichini I, et al: Epidermal growth factor receptor gene and protein and gefitinib sensitivity in non-small-cell lung cancer. J Natl Cancer Inst 97: 643-655, 2005.

11. Mendelsohn J and Baselga J: Status of epidermal growth factor receptor antagonists in the biology and treatment of cancer. J Clin Oncol 21: 2787-2799, 2003.

12. Yoshida T, Zhang G and Haura EB: Targeting epidermal growth factor receptor: Central signaling kinase in lung cancer. Biochem Pharmacol 80: 613-623, 2010.

13. Xu N, Fang W, Mu L, Tang Y, Gao L, Ren S, Cao D, Zhou L, Zhang A, Liu D, et al: Overexpression of wildtype EGFR is tumorigenic and denotes a therapeutic target in non-small cell lung cancer. Oncotarget 7: 3884-3896, 2016.

14. Sabattini S, Mancini FR, Marconato L, Bacci B, Rossi F, Vignoli $M$ and Bettini G: EGFR overexpression in canine primary lung cancer: Pathogenetic implications and impact on survival. Vet Comp Oncol 12: 237-248, 2014.

15. Tebbutt N,Pedersen MW and Johns TG: Targeting the ERBB family in cancer: Couples therapy. Nat Rev Cancer 13: 663-673, 2013.

16. Bebb G, Smith C, Rorke S, Boland W, Nicacio L, Sukhoo R and Brade A: Phase I clinical trial of the anti-EGFR monoclonal antibody nimotuzumab with concurrent external thoracic radiotherapy in Canadian patients diagnosed with stage IIb, III or IV non-small cell lung cancer unsuitable for radical therapy. Cancer Chemother Pharmacol 67: 837-845, 2011.

17. Rojo F, Gracias E, Villena N, Cruz T, Corominas JM, Corradino I, Cedeño M, Campas C, Osorio M, Iznaga N, et al: Pharmacodynamic trial of nimotuzumab in unresectable squamous cell carcinoma of the head and neck: A SENDO Foundation study. Clin Cancer Res 16: 2474-2482, 2010.

18. Crombet T, Osorio M, Cruz T, Roca C, del Castillo R, Mon R, Iznaga-Escobar N, Figueredo R, Koropatnick J, Renginfo E, et al: Use of the humanized anti-epidermal growth factor receptor monoclonal antibody h-R3 in combination with radiotherapy in the treatment of locally advanced head and neck cancer patients. J Clin Oncol 22: 1646-1654, 2004.
19. Ramos TC, Figueredo J, Catala M, González S, Selva JC, Cruz TM, Toledo C, Silva S, Pestano Y, Ramos M, et al: Treatment of high-grade glioma patients with the humanized anti-epidermal growth factor receptor (EGFR) antibody h-R3: Report from a phase I/II trial. Cancer Biol Ther 5: 375-379, 2006.

20. Ma NY, Cai XW, Fu XL, Li Y, Zhou XY, Wu XH, Hu XC, Fan M, Xiang JQ, Zhang YW, et al: Safety and efficacy of nimotuzumab in combination with radiotherapy for patients with squamous cell carcinoma of the esophagus. Int J Clin Oncol 19: 297-302, 2014.

21. Herbst RS and Bunn PA Jr: Targeting the epidermal growth factor receptor in non-small cell lung cancer. Clin Cancer Res 9: 5813-5824, 2003

22. Raben D, Helfrich B, Chan DC, Ciardiello F, Zhao L, Franklin W, Barón AE, Zeng C, Johnson TK and Bunn PA Jr: The effects of cetuximab alone and in combination with radiation and/or chemotherapy in lung cancer. Clin Cancer Res 11: 795-805, 2005.

23. Cascone T, Morelli MP and Ciardiello F: Small molecule epidermal growth factor receptor (EGFR) tyrosine kinase inhibitors in non-small cell lung cancer. Ann Oncol 17 (Suppl 2): ii46-ii48, 2006.

24. Babu KG, Prabhash K, Vaid AK, Sirohi B, Diwakar RB, Rao R, Kar M, Malhotra H, Nag S, Goswami C, et al: Nimotuzumab plus chemotherapy versus chemotherapy alone in advanced non-small-cell lung cancer: A multicenter, randomized, open-label Phase II study. Onco Targets Ther 7: 1051-1060, 2014.

25. Diaz Miqueli A, Blanco R, Garcia B, Badia T, Batista AE, Alonso R and Montero E: Biological activity in vitro of anti-epidermal growth factor receptor monoclonal antibodies with different affinities. Hybridoma (Larchmt) 26: 423-431, 2007.

26. Akashi Y, Okamoto I, Iwasa T, Yoshida T, Suzuki M, Hatashita E, Yamada Y, Satoh T, Fukuoka M, Ono K and Nakagawa K: Enhancement of the antitumor activity of ionising radiation by nimotuzumab, a humanised monoclonal antibody to the epidermal growth factor receptor, in non-small cell lung cancer cell lines of differing epidermal growth factor receptor status. $\mathrm{Br}$ J Cancer 98: 749-755, 2008.

27. Maioli E, Torricelli C, Fortino V, Carlucci F, Tommassini V and Pacini A: Critical appraisal of the MTT assay in the presence of rottlerin and uncouplers. Biol Proced Online 11: 227-240, 2009.

28. Vindel $\varnothing v$ LL, Christensen IJ and Nissen NI: A detergent-trypsin method for the preparation of nuclei for flow cytometric DNA analysis. Cytometry 3: 323-327, 1983.

29. Casimiro MC, Velasco-Velázquez M, Aguirre-Alvarado C and Pestell RG: Overview of cyclins D1 function in cancer and the CDK inhibitor landscape: Past and present. Expert Opin Investig Drugs 23: 295-304, 2014.

30. Ramakrishnan MS, Eswaraiah A, Crombet T, Piedra P, Saurez G, Iyer $\mathrm{H}$ and Arvind AS: Nimotuzumab, a promising therapeutic monoclonal for treatment of tumors of epithelial origin. MAbs 1: 41-48, 2009.

31. Massimino M, Bode U, Biassoni $\mathrm{V}$ and Fleischhack G: Nimotuzumab for pediatric diffuse intrinsic pontine gliomas. Expert Opin Biol Ther 11: 247-256, 2011.

32. Ramos-Suzarte M, Lorenzo-Luaces P, Lazo NG, Perez ML, Soriano JL, Gonzalez CE, Hernadez IM, Albuerne YÁ, Moreno BP, Alvarez ES, et al: Treatment of malignant, non-resectable, epithelial origin esophageal tumours with the humanized anti-epidermal growth factor antibody nimotuzumab combined with radiation therapy and chemotherapy. Cancer Biol Ther 13: 600-605, 2012

33. Wang Y, Pan L, Sheng XF, Chen S and Dai JZ: Nimotuzumab, a humanized monoclonal antibody specific for the EGFR, in combination with temozolomide and radiation therapy for newly diagnosed glioblastoma multiforme: First results in Chinese patients. Asia Pac J Clin Oncol 12: e23-e29, 2016.

34. Zhao KL, Hu XC, Wu XH, Fu XL, Fan M and Jiang GL: A phase I dose escalation study of nimotuzumab in combination with concurrent chemoradiation for patients with locally advanced squamous cell carcinoma of esophagus. Invest New Drugs 30: 1585-1590, 2012.

35. Ji YH, Yang XY, Wu JQ, Huo XQ, Li WW, Li GJ, Mu YL and Lu P: Nimotuzumab with cisplatin or fluorouracil on human esophageal squamous cell carcinoma EC1 cells. Eur Rev Med Pharmacol Sci 19: 586-591, 2015.

36. Du F, Zheng Z, Shi S, Jiang Z, Qu T, Yuan X, Sun Y, Song Y, Yang L, Zhao J, et al: S-1 and cisplatin with or without nimotuzumab for patients with untreated unresectable or metastatic gastric cancer: A randomized, open-label phase 2 trial. Medicine (Baltimore) 94: e958, 2015. 